\title{
Overweight and obesity among children under five in Ethiopia: further analysis of 2016 national demographic health survey: a case control study
}

\author{
Haftom Gebrehiwot Weldearegay ${ }^{*^{*} \mathbb{D}}$, Tesfay Gebregzabher Gebrehiwot ${ }^{1}$, Mulugeta Woldu Abrha ${ }^{2}$ \\ and Afework Mulugeta'
}

\begin{abstract}
Objective: The objective of this study was to assess the determinants of overweight and obesity among children under 5 years in Ethiopia.

Results: Data from a total of 672 (224 cases and 448 controls) under 5 years of age children were included in the study. Urban residence ( $A O R=2.63,95 \% \mathrm{Cl} 1.29,5.34)$, boys ( $\mathrm{AOR}=1.56,95 \% \mathrm{Cl} 1.10,2.22$ ) and age of the child less than 6 months ( $A O R=3.40,95 \% \mathrm{Cl} 2.05,5.64$ ) were the determinants for being childhood overweight and obesity.
\end{abstract}

Keywords: Overweight and obesity, EDHS, Case-control study, Ethiopia

\section{Introduction}

Overweight and obesity are defined as abnormal or excessive accumulation of fat which may impair health $[1,2]$. A combination of childhood overweight and obesity are of the most serious public health challenges of the twenty first century [2]. The prevalence of childhood overweight and obesity is increasing in all countries, with the most rapid rise in low and middle-income countries with majority of overweight and obese children live in developing countries, where the rate of increase has been more than $30 \%$ higher than that of developed countries [3-5].

In Africa, the number of overweight and obese children has nearly doubled from 5.4 million in 1990 to 10.3 million in 2014 [6]. The occurrence of infant, childhood and adolescent overweight and obesity may be plateauing in African settings, but in absolute numbers there are more overweight and obese children living in low and

\footnotetext{
*Correspondence: haftom1224@gmail.com

${ }^{1}$ College of Health Sciences, Mekelle University, Mekelle, Ethiopia

Full list of author information is available at the end of the article
}

middle-income countries compared to in high-income countries [5, 7].

Moreover, children with overweight and obesity suffer severe health consequences in childhood and are at high risk of becoming obese adults, resulting increased risk of non-communicable diseases and reproductive disorders later in their life $[1,4]$. Many factors can be linked with overweight and obesity in children. Economic growth or socioeconomic status, maternal level of education, marital status, smoking during pregnancy, sex of the child, birth weight and the child's birth rank, area of residence, location of residence, age of the child, BMI of parents have been found as risk factors of childhood overweight and obesity [5, 8-10].

In Ethiopia, a low-income country which is still scarred by childhood malnutrition, childhood obesity is not yet perceived as an emerging health issue and receives little attention. According to UNICEF 2017 annual report there is overall increment of prevalence of overweight among children from 1.7 to $3.6 \%$ in Ethiopia [11]. Therefore, within this evidence, there are incongruent results in the determinant factors of overweight and obesity among literatures in Ethiopia. This study aimed to identify the 
determinants of overweight and obesity among children in Ethiopia. Thus, this finding highlighted in designing effective preventive strategies to clench the rising burden of early childhood overweight and obesity and its consequential morbidity and mortality in adulthood.

\section{Main texts \\ Methods and materials \\ Data source}

We used a secondary data analysis from 2016 Ethiopia Demographic and Health Survey. It is the fourth DHS conducted in Ethiopia by the Central Statistical Agency (CSA) through the request of Federal Ministry of Health (FMoH) in collaboration with United States Agency for International Development.

\section{Sampling techniques and population}

We used data from the 2016 Ethiopian Demographic Health Survey (EDHS) assessment. The EDHS was a national representative sample of 18,008 households and 10,752 children under age 5 years were eligible for height and weight measurements [12]. The 'child record' (age ranged from 0 to 59 months) data set was downloaded from the MEASURE DHS website. Child and maternal anthropometric data and various pertinent socio demographic variables were extracted from the data sets.

The nutritional status of children was categorized into normal weight (above minus two standard deviations $(-2 \mathrm{SD})$ and below plus two standard deviations (+2 SD) from the median of the reference population), underweight (below minus two standard deviations $(-2$ $\mathrm{SD})$ from the median of the reference population) and overweight and obese (more than two standard deviations (+2 SD) above the median of the reference population) based on the BMI Z scores.

We retrieved children with underweight and those whose BMI z-scores were missing or was recorded as "Height out of plausible limits" or "Age in days out of plausible limits" or "Flagged cases", as their values were unusable since they were recorded in the database under special codes which corresponded either to responses that were considered inconsistent with other response in the questionnaire and thought to be probably an error, or to responses whose value was "Don't know". All eligible overweight and obese children $(n=224)$ were included into the analysis as cases. Similarly, 448 normal weight children were selected randomly as controls from 7168 normal weight children living with their mothers and incorporated into the further analysis.

Outcome variable: Children who had BMI z-score over 2 were classified as overweight and obese children characterized as cases. And those who had BMI z-score ranged from -2 to 2 were classified as normal weight children, which are considered as controls [13].

\section{Data analysis}

Data analyses were carried out using SPSS $21^{\mathrm{TM}}$ - software. Variables with $\mathrm{p}<0.25$ at bivariate analysis were entered to multivariable logistic regression analysis using the forward likelihood ratio method. Finally, $\mathrm{p}<0.01$ in multivariable analysis was considered to declare statistically significant association between predictors and outcome of interest.

\section{Results}

\section{Socio-demographic characteristics of under five children}

We enrolled 224 cases and 448 controls of children aged 0-59 months old. Mean age of cases was $23.6(\mathrm{SD} \pm 16.3)$ months and mean age of controls was 32.3 ( $\mathrm{SD} \pm 16.6)$ months. Two-third, 150 (67.0\%) of the cases and majority $382(85.3 \%)$ of the controls were from rural areas. Nearly one-fifth $46(20.5 \%)$ of the cases and 71 (15.8\%) controls were from Oromia region.

Sixty-two percent $(n=141)$ of cases belonged to the low birth rank (1-3 births) and almost half 230 (51.3\%) of controls belonged to high birth rank category ( $>3$ births) (Table 1).

\section{Maternal and household characteristics}

Almost half 120 (53.6\%) of mothers of the cases and six out of ten $286(63.8 \%)$ mothers of the controls didn't attend formal education. Majority 195 (87.1\%) of mothers of the cases and nine of ten mothers 420 (93.8\%) of controls were not reading newspapers or magazines at all. Six out of ten 146 (65.2\%) of mothers of cases and above two-third 311 (69.4\%) of mothers of controls had normal BMI. Only one-third 74 (33.0\%) of the cases belonged to richest category and $162(36.2 \%)$ of the controls were poorest. Above two-third 155 (69.2\%) of the households of the cases and half $243(54.2 \%)$ of the households of controls had four and above children (Table 2).

\section{Determinants of child overweight and obesity in Ethiopia}

Residence, sex and child age were significantly associated with childhood overweight and obesity in Ethiopia. The odds of overweight or obesity was 2.6 times higher among urban children than rural children $(\mathrm{AOR}=2.6,95 \% \mathrm{CI}$ $1.3,5.3)$. The odds of overweight were 1.5 times higher in boys compared to girls (AOR $=1.6,95 \%$ CI 1.1, 2.2). Less than 6 months old children had three times higher odds of becoming overweight or obese (AOR $=3.4,95 \% \mathrm{CI} 2.1$, 5.6) compared to $24-59$ months old children. Similarly, 6-24 months old children had two times higher odds of becoming obese compared to 24-59 months old children $(\mathrm{AOR}=2.4,95 \% \mathrm{CI} 1.6,3.6)$ (Table 3). 
Table 1 Socio-demographic characteristics of under five children, EDHS 2016

\begin{tabular}{|c|c|c|}
\hline Characteristics & $\begin{array}{l}\text { Cases } \\
(\mathrm{N}=224) \mathrm{n}(\%)\end{array}$ & $\begin{array}{l}\text { Controls } \\
(\mathrm{N}=448) \mathrm{n}(\%)\end{array}$ \\
\hline \multicolumn{3}{|l|}{ Place of residence } \\
\hline Urban & $74(33.0)$ & $66(14.7)$ \\
\hline Rural & $150(67.0)$ & $382(85.3)$ \\
\hline \multicolumn{3}{|l|}{ Region } \\
\hline Tigray & $16(7.1)$ & $42(9.4)$ \\
\hline Afar & $11(4.9)$ & $42(9.4)$ \\
\hline Amhara & $15(6.7)$ & $47(10.5)$ \\
\hline Oromia & $46(20.5)$ & $71(15.8)$ \\
\hline Ethio-Somalia & $18(8.0)$ & $54(12.5)$ \\
\hline Benishangul-Gumz & $14(6.2)$ & $35(7.8)$ \\
\hline SNNPR & $43(19.2)$ & $68(15.2)$ \\
\hline Gambela & $8(3.6)$ & $31(6.9)$ \\
\hline Hareri & $12(5.4)$ & $15(3.3)$ \\
\hline Addis Ababa & $32(14.3)$ & $16(3.6)$ \\
\hline Dire Dawa & $9(4.1)$ & $25(5.6)$ \\
\hline \multicolumn{3}{|l|}{ Sex of child } \\
\hline Boys & $129(57.6)$ & $215(48.0)$ \\
\hline Girls & $95(42.4)$ & $233(52.0)$ \\
\hline \multicolumn{3}{|l|}{ Birth rank } \\
\hline Low birth rank & $141(62.9)$ & $218(48.7)$ \\
\hline High birth rank & $83(37.1)$ & $230(51.3)$ \\
\hline \multicolumn{3}{|l|}{ Age of child } \\
\hline Less than 6 months & $46(20.5)$ & $43(9.6)$ \\
\hline $6-24$ months & 78 (34.8) & $108(24.1)$ \\
\hline 24-59 months & $100(44.6)$ & $297(66.3)$ \\
\hline
\end{tabular}

\section{Discussion}

This study showed sex, age of the child, and place of residence were the determinants of overweight and obesity among under-five children in Ethiopia. Younger children had higher odds of becoming overweight or obese than their older counterparts. This is corroborated with studies done in Hawassa, Ethiopia [14], Gondar, Ethiopia [15], Cameroon [16], SSA [9] and Malaysia [17]. This might be explained by the fact that as age of the child increases, the chance to join kindergarten would increase and hence may attribute to increased physical activity which ultimately would lead to increased metabolic activity and energy requirements. This finding suggests that age specific nutritional counseling strategies during childhood are necessary.

Children who were living in urban areas were more affected by overweight and obesity. This is in line with the study done in Hawai [18], Peru [19] and Poland $[20,21]$. This might be partly explained by differences in lifestyles, access to food supply, increased intake of energy-dense foods and rapid nutritional transition
Table 2 Household and maternal characteristics of under five children, EDHS 2016

\begin{tabular}{|c|c|c|}
\hline Characteristics & $\begin{array}{l}\text { Cases } \\
(\mathrm{N}=224) \mathrm{n}(\%)\end{array}$ & $\begin{array}{l}\text { Controls } \\
(\mathrm{N}=448) \mathrm{n}(\%)\end{array}$ \\
\hline \multicolumn{3}{|l|}{ Mother's educational level } \\
\hline No education & $120(53.6)$ & $286(63.8)$ \\
\hline Primary & $64(28.6)$ & $125(27.9)$ \\
\hline Secondary & $25(11.2)$ & $22(4.9)$ \\
\hline Higher & $15(6.7)$ & $15(3.3)$ \\
\hline \multicolumn{3}{|c|}{ Frequency of reading newspapers/magazines } \\
\hline Not at all & $195(87.1)$ & $420(93.8)$ \\
\hline Less than a week & $17(7.6)$ & $25(5.6)$ \\
\hline At least a week & $12(5.4)$ & $3(0.7)$ \\
\hline \multicolumn{3}{|c|}{ Frequency of listening radio } \\
\hline Not at all & $155(69.2)$ & $351(78.3)$ \\
\hline Less than a week & $30(13.4)$ & $40(8.9)$ \\
\hline At least a week & $39(17.4)$ & $57(12.7)$ \\
\hline \multicolumn{3}{|l|}{ Frequency of watching TV } \\
\hline Not at all & $158(70.5)$ & $372(83.0)$ \\
\hline Less than a week & $12(5.4)$ & $31(6.9)$ \\
\hline At least a week & $54(24.1)$ & $45(10.0)$ \\
\hline \multicolumn{3}{|l|}{ Mothers'BMI } \\
\hline Under weight & $33(14.7)$ & $84(18.8)$ \\
\hline Normal weight & $146(65.2)$ & $311(69.4)$ \\
\hline Overweight and obese & $45(20.1)$ & $53(11.8)$ \\
\hline \multicolumn{3}{|l|}{ Wealth index } \\
\hline Poorest & $61(27.2)$ & $162(36.2)$ \\
\hline Poorer & $27(12.1)$ & $78(17.4)$ \\
\hline Middle & $28(12.5)$ & $68(15.2)$ \\
\hline Richer & $34(15.2)$ & $56(12.5)$ \\
\hline Richest & $74(33.0)$ & $84(18.8)$ \\
\hline \multicolumn{3}{|l|}{ Children ever born } \\
\hline Four and above & $155(69.2)$ & $243(54.2)$ \\
\hline Less than four & 69 (30.8) & $205(45.8)$ \\
\hline
\end{tabular}

in urban areas which makes it vital for the health care providers to take the lead in practicing primary prevention and early identification of obese children in the urban communities of the country.

The relation between sex of child and overweight or obesity showed that boys were at found to be at a higher odds of overweight or obesity than girls. This is consistent with studies done in Ghana [22], Cameroon [16], China [23] and Brazil [24]. But, it was in a sharp contrast with study findings reported elsewhere [2527] where girls were found to be affected more than the boys and where sex had no significant effect on child overweight and obesity [28]. This partly might be the result of interactions between genetic, environmental factors, metabolism, eating and physical activity behavior, and social and individual psychology [29]. 
Table 3 Determinants of child overweight and obesity in Ethiopia, EDHS, 2016

\begin{tabular}{|c|c|c|c|c|}
\hline \multirow[t]{2}{*}{ Characteristics } & \multirow[t]{2}{*}{ Cases, n (\%) } & \multirow[t]{2}{*}{ Controls, n (\%) } & \multicolumn{2}{|c|}{ Odds ratio and $95 \% \mathrm{Cl}$} \\
\hline & & & Crude & Adjusted \\
\hline \multicolumn{5}{|l|}{ Place of residence } \\
\hline Urban & $74(33.0)$ & $66(14.7)$ & $2.86(1.95-4.18)$ & $2.63(1.29-5.34)^{*}$ \\
\hline Rural & $150(67.0)$ & $382(85.3)$ & 1 & 1 \\
\hline \multicolumn{5}{|c|}{ Mother's educational level } \\
\hline No education & $120(53.6)$ & $286(63.8)$ & $0.42(0.20-0.89)$ & $1.41(0.44-4.51)$ \\
\hline Primary & $64(28.6)$ & $125(27.9)$ & $0.51(0.24-1.11)$ & $0.85(0.31-2.32)$ \\
\hline Secondary & $25(11.2)$ & $22(4.9)$ & $1.14(0.45-2.84)$ & $1.05(0.38-2.94)$ \\
\hline Higher & $15(6.7)$ & $15(3.3)$ & 1 & 1 \\
\hline \multicolumn{5}{|c|}{ Frequency of reading newspapers } \\
\hline Not at all & $195(87.1)$ & $420(93.8)$ & $0.12(0.03-0.42)$ & $0.26(0.06-1.11)$ \\
\hline Less than a week & $17(7.6)$ & $25(5.6)$ & $0.17(0.04-0.69)$ & $0.17(0.04-0.78)$ \\
\hline At least a week & $12(5.4)$ & $3(0.7)$ & 1 & \\
\hline \multicolumn{5}{|c|}{ Frequency of listening radio } \\
\hline Not at all & $155(69.2)$ & $351(78.3)$ & $0.65(0.41-1.01)$ & \\
\hline Less than a week & $30(13.4)$ & $40(8.9)$ & $1.10(0.59-2.05)$ & \\
\hline At least a week & $39(17.4)$ & $57(12.7)$ & 1 & \\
\hline \multicolumn{5}{|c|}{ Frequency of watching TV } \\
\hline Not at all & $158(70.5)$ & $372(83.0)$ & $0.35(0.23-0.55)$ & $0.69(0.32-1.53)$ \\
\hline Less than a week & $12(5.4)$ & $31(6.9)$ & $0.32(0.15-0.70)$ & $0.42(0.17-1.05)$ \\
\hline At least a week & $54(24.1)$ & $45(10.0)$ & 1 & 1 \\
\hline \multicolumn{5}{|l|}{ Wealth index } \\
\hline Poorest & $61(27.2)$ & $162(36.2)$ & $0.43(0.28-0.66)$ & $1.22(0.55-2.68)$ \\
\hline Poorer & $27(12.1)$ & $78(17.4)$ & $0.39(0.23-0.67)$ & $1.1(0.51-2.86)$ \\
\hline Middle & $28(12.5)$ & $68(15.2)$ & $0.47(0.27-0.80)$ & $1.45(0.62-3.40)$ \\
\hline Richer & $34(15.2)$ & $56(12.5)$ & $0.67(0.41-1.17)$ & $2.02(0.88-4.61)$ \\
\hline Richest & $74(33.0)$ & $84(18.8)$ & 1 & 1 \\
\hline \multicolumn{5}{|l|}{ Children ever born } \\
\hline Four and above & $155(69.2)$ & $243(54.2)$ & $1.90(1.35-2.66)$ & $1.20(0.62-2.32)$ \\
\hline Greater than four & $69(30.8)$ & $205(45.8)$ & 1 & 1 \\
\hline \multicolumn{5}{|l|}{ Sex of child } \\
\hline Boys & $129(57.6)$ & $215(48.0)$ & $1.47(1.07-2.03)$ & $1.56(1.10-2.22)^{*}$ \\
\hline Girls & $95(42.4)$ & $233(52.0)$ & 1 & 1 \\
\hline \multicolumn{5}{|l|}{ BMI of mother } \\
\hline Under weight & $33(14.7)$ & $84(18.8)$ & $0.46(0.26-0.82)$ & $0.91(0.47-1.77)$ \\
\hline Normal weight & $146(65.2)$ & $311(69.4)$ & $0.55(0.36-0.86)$ & $0.94(0.54-1.62)$ \\
\hline Overweight/obese & $45(20.1)$ & $53(11.8)$ & 1 & 1 \\
\hline \multicolumn{5}{|l|}{ Birth rank } \\
\hline Low birth rank (1-3) & $141(62.9)$ & $218(48.7)$ & $1.79(1.29-2.49)$ & $1.3(0.67-2.51)$ \\
\hline High birth rank (>3) & $83(37.1)$ & $230(51.3)$ & 1 & 1 \\
\hline \multicolumn{5}{|l|}{ Age of child } \\
\hline Less than 6 months & $46(20.5)$ & $43(9.6)$ & $3.18(1.98-5.10)$ & $3.40(2.05-5.64)^{*}$ \\
\hline $6-24$ months & $78(34.8)$ & $108(24.1)$ & $2.15(1.48-3.10)$ & $2.40(1.61-3.58)^{*}$ \\
\hline 24-59 months & $100(44.6)$ & $297(66.3)$ & 1 & 1 \\
\hline
\end{tabular}

Italic values indicate were demographic characteristic frequency of participants

\section{Conclusions}

The finding of this study revealed that age, place of residence and sex of the children were the determinants of childhood overweight and obesity in Ethiopia. Therefore, nutrition education on feeding practices and physical activities should be boosted in the urban setting. Besides, 
targeted and age-specific infant and young child feeding practices are recommended to improve nutritional outcomes of children. Further study is recommended to explore other potential risk factors with the emerging problem of childhood overweight and obesity in Ethiopia.

\section{Limitation of the study}

This secondary data analysis only focused on the specific main factors of overweight/obesity, did not include dietary intake data and feeding habits of the children.

\section{Abbreviations}

BMI: body mass index; Cl: confidence interval; EDHS: Ethiopia Demographic and Health Survey; CSA: Central Statistical Agency.

\section{Acknowledgements}

Our heartfelt thanks go to Central statistical agency (CSA) and MEASURE DHS project staff for providing free access to the data.

\section{Authors' contributions}

HGW: conceived the idea, designed, performed statistical analysis and write the manuscript. TGG and AM: critically reviewed the manuscript and provided feedback. MWA: reviewed the manuscript and provided useful comments during the analysis and interpretation. All authors read and approved the final manuscript.

\section{Funding}

Not applicable.

\section{Availability of data and materials}

The data that support the findings of this study are available from MEASURE $\mathrm{DHS}$ project but restrictions apply to the availability of these data, which were used under license for the current study, and so are not publicly available. Data are however available from the MEASURE DHS project upon reasonable online request after submission of concept paper".

\section{Ethics approval and consent to participate}

The primary researchers of the 2016 Ethiopia Demographic Health Survey obtained ethical clearance, and there was no need of ethical clearance for this secondary analysis. However, permission was obtained from measure DHS project website to access the dataset.

\section{Consent for publication}

Not applicable.

\section{Competing interests}

The authors declare that they have no competing interests.

\section{Author details}

${ }^{1}$ College of Health Sciences, Mekelle University, Mekelle, Ethiopia. ${ }^{2}$ Tigray Health Research Institute, Mekelle, Ethiopia.

Received: 3 September 2019 Accepted: 18 October 2019 Published online: 31 October 2019

\section{References}

1. World Health Organization. Childhood overweight and obesity on the rise, 2010. (WWW document). http://www.who.int. Accessed 21 July 2018.

2. Edris M. Assessment of nutritional status of preschool children of Gumbrit, North West Ethiopia. Ethiop J Health Dev. 2007:21(2):125-9.

3. UNICEF, WHO, World Bank. Levels and trends in child malnutrition: UNICEF-WHO-World Bank joint child malnutrition estimates. New York, Geneva, Washington DC: UNICEF, WHO, World Bank; 2015.
4. Due P, Damsgaard MT, Rasmussen M, Holstein BE, Wardle J, Merlo J, et al. Socioeconomic position, macroeconomic environment and overweight among adolescents in 35 countries. Int J Obes. 2009:33:1084-93.

5. World Health Organization. Consideration of the evidence on childhood obesity for the Commission on Ending Childhood Obesity Report of the Ad hoc Working Group on Science and Evidence for Ending Childhood Obesity Geneva. Switzerland: WHO; 2016.

6. WHO. Commission presents its final report, calling for high-level action to address major health challenge, 25 January 2016. https://www.who.int/ end-childhood-obesity/news/launch-final-report/en/. Accessed 24 Sept 2018.

7. Ng M, Fleming T, Robinson M, Thomson B, Graetz N, Margono C, et al. Global, regional, and national prevalence of overweight and obesity in children and adults during 1980-2013: a systematic analysis for the global burden of disease study, 2013. Lancet. 2014;384:766-81.

8. Gebremedhin S. Prevalence and differentials of overweight and obesity in preschool children in Sub Saharan Africa. BMJ Open. 2015;5(12):e009005. https://doi.org/10.1136/bmjopen-2015-009005.

9. Toselli S, Zaccagni L, Celenza F, Albertini A, Gualdi-Russo E. Risk factors of overweight and obesity among preschool children with different ethnic background. Endocrine. 2015;49(3):717-25. https://doi.org/10.1007/s1202 0-014-0479-4

10. Taveras EM, Gillman MW, Kleinman K, Rich-Edwards JW, Rifas-Shiman SL. Racial/ethnic differences in early-life risk factors for childhood obesity. Pediatrics. 2010;125:686-95.

11. UNICEF Annual Report 2016, Ethiopia. www.unicef.org/about/annualrepo rt/files/Ethiopia_2016_COAR.pdf. Accessed 18 Aug 2018.

12. Central Statistical Agency Ethiopia and ICF International. Ethiopia demographic and health survey. Addis Ababa: Central Statistical Agency Ethiopia and ICF International; 2016.

13. World Health Organization. Training Course on Child Growth Assessment. Geneva: World Health Organization; 2008.

14. Tesedeke W, Tefera B. Prevalence and determinant factors of overweight and obesity among preschool children in Hawassa. Food Sci Qual Manag. 2014:29:1-5.

15. Sorrie MB, Yesuf ME, GebreMichael TG. Overweight/obesity and associated factors among preschool children in Gondar City, Northwest Ethiopia: a cross-sectional study. PLoS ONE. 2017;12(8):e0182511.

16. Tchoubi S, Sobngwi-Tambekou J, Noubiap JJN, Asangbeh SL, Nkoum BA, Sobngwi E. Prevalence and risk factors of overweight and obesity among children aged 6-59 Months in Cameroon: a multistage, stratified cluster sampling nationwide survey. PLOS ONE. 2015;10(12):e0143215. https:// doi.org/10.1371/journal.pone.0143215.

17. Sidik SM, Rampal L. The prevalence and factors associated with obesity among adult women in Selangor, Malaysia. Asia Pac Fam Med. 2009:8:1-6.

18. Stark MJ, Niederhauser VP, Camacho JM, Shirai L. Prevalence of overweight and obesity in children at health. HAWAI'I Med J. 2011;70:27-9.

19. Hernández-Vásquez A, Bendezú-Quispe G, Santero M, Azañedo D. Prevalence of childhood obesity by sex and regions in Peru, 2015. Rev Esp Salud Pública. 2016;90(13):e1-10.

20. Bac A, Woźniacka R, Matusik S, Golec J, Golec E. Prevalence of overweight and obesity in children aged 6-13 years alarming increase in obesity in Cracow, Poland. Eur J Pediatr. 2012;171(2):245-51. https://doi. org/10.1007/s00431-011-1519-1.

21. Markowska M, Przychodni AM, Nowak-Starz G, Cieśla E. Frequency of overweight and obesity occurrence among Polish children in relation to the place of residence, the education level of parents and the number children in the family. Anthropol Rev. 2017;80(4):381-92.

22. Richmond A, Anna L, Grace SM, Helena N, Esi C, Patricia B. Prevalence and predictors of overweight \& obesity among school-aged children in urban Ghana. BMC Obesity. 2017:4:38.

23. Zhangbin Y, Han S, Chu J, Zhongya X, Zhu C, Guo X. Trends in overweight and obesity among children and adolescents in China from 1981 to 2010 a meta-analysis. PLoS ONE. 2012;7(12):e51949. https://doi.org/10.1371/ journal.pone.0051949.

24. Menezes IC, Neutzling MB, Taddei JD. Risk factors for overweight and obesity in adolescents of a Brazilian University: a case-control study. Nutr Hosp. 2009;24(1):17-24. 
25. Rooney BL, Mathiason MA, Schauberger CW. Predictors of obesity in childhood, adolescence, and adulthood in a birth cohort. Matern Child Health J. 2010;15(8):1166-75.

26. Reilly JJ, Armstrong J, Dorosty AR, Emmett PM, Ness A, Rogers I, et al. Early life risk factors for obesity in childhood: cohort study. BMJ. 2005;330(7504):1357.

27. Kitsantas P, Gaffney KF. Risk profiles for overweight/obesity among preschoolers. Early Hum Dev. 2010;86(9):563-8. https://doi.org/10.1016/j. earlhumdev.2010.07.006.

28. Tabacchi G, Giammanco S, La Guardia M, Giammanco M. A review of the literature and a new classification of the early determinants of childhood obesity: from pregnancy to the first years of life. Nutr Res. 2007:27(10):587-604.

29. Damaris M, Nguimbus E, Bikono F. Prevalence of overweight and obesity among rural preschool school children Cameroon. Int J Adv Res. 2017;5(3):673-8. https://doi.org/10.21474/ijar01/3557.

\section{Publisher's Note}

Springer Nature remains neutral with regard to jurisdictional claims in published maps and institutional affiliations.
Ready to submit your research? Choose BMC and benefit from:

- fast, convenient online submission

- thorough peer review by experienced researchers in your field

- rapid publication on acceptance

- support for research data, including large and complex data types

- gold Open Access which fosters wider collaboration and increased citations

- maximum visibility for your research: over $100 \mathrm{M}$ website views per year

At BMC, research is always in progress.

Learn more biomedcentral.com/submissions 